Article

\title{
Potassium Hexacyanoferrate (III)-Catalyzed Dimerization of Hydroxystilbene: Biomimetic Synthesis of Indane Stilbene Dimers
}

\author{
Jing-Shan Xie ${ }^{1,2}$, Jin Wen ${ }^{3}$, Xian-Fen Wang ${ }^{1}$, Jian-Qiao Zhang ${ }^{1}$, Ji-Fa Zhang ${ }^{1}$, Yu-Long Kang ${ }^{1}$, \\ You-Wei Hui ${ }^{2}$, Wen-Sheng Zheng ${ }^{1, *}$ and Chun-Suo Yao ${ }^{1, *}$ \\ Received: 16 November 2015 ; Accepted: 9 December 2015 ; Published: 18 December 2015 \\ Academic Editor: Roman Dembinski \\ 1 State Key Laboratory of Bioactive Substance and Function of Natural Medicines, Institute of Materia \\ Medica, Chinese Academy of Medical Sciences \& Peking Union Medical College, Beijing 100050, China; \\ jingshan508@126.com (J.-S.X.); wxf312936046@163.com (X.-F.W.); jqzhang@imm.ac.cn (J.-Q.Z.); \\ jifa17@163.com (J.-F.Z.); kangyulongzyy@imm.ac.cn (Y.-L.K.) \\ 2 School of Chemical Engineering, Northwest University, Xi'an 710069, China; youweixi163@163.com \\ 3 Chinese Pharmaceutical Association, Beijing 100022,China; Jin_ann1463@163.com \\ * Correspondence: zhengwensheng@imm.ac.cn (W.-S.Z.); yaocs@imm.ac.cn (C.-S.Y.); \\ Tel.: +86-010-6316-5233 (W.-S.Z.); +86-010-6021-2110 (C.-S.Y.)
}

\begin{abstract}
Using potassium hexacyanoferrate (III)-sodium acetate as oxidant, the oxidative coupling reaction of isorhapontigenin and resveratrol in aqueous acetone resulted in the isolation of three new indane dimers 4, 6, and 7, together with six known stilbene dimers. Indane dimer 5 was obtained for the first time by direct transformation from isorhapontigenin. The structures and relative configurations of the dimers were elucidated using spectral analysis, and their possible formation mechanisms were discussed. The results indicate that this reaction could be used as a convenient method for the semi-synthesis of indane dimers because of the mild conditions and simple reaction products.
\end{abstract}

Keywords: potassium hexacyanoferrate (III); indane stilbene dimer; biomimetic synthesis; hydroxystilbene

\section{Introduction}

Stilbene dimers with indane skeletons possess a wide range of biological activity [1,2] and novel structures which are difficult to achieve by common organic reactions on account of their intricate architectures and chiral centers. As many of these compounds are exclusively obtained by extraction from natural sources, the studies of biological properties are limited by their extreme scarcity. This has made the synthesis of stilbene dimers, especially indane dimers a popular research topic [3]. Indane stilbene dimers such as quadragularin $\mathrm{A}$, pallidol, ampelopsin $\mathrm{F}$, paucifloral $\mathrm{F}$, ampelopsin D, and caraphenol $C$ have been successfully synthesized [4-10]. However, the complexity of the synthetic routes has hindered further studies on these indane derivatives, and the search for simple and convenient synthetic routes to obtain abundant samples is of significant interest. As a conventional inorganic one-electron oxidant, potassium hexacyanoferrate (III) $\left(\mathrm{K}_{3} \mathrm{Fe}(\mathrm{CN})_{6}\right)$ has been reported to generate resveratrol trans-dehydrodimer, $\varepsilon$-viniferin and indane dimers in the oxidative coupling reaction of resveratrol (1) [11,12]. However, a detailed study of this reaction has yet to be reported. In our previous paper [13], we reported that the transformation of isorhapontigenin (2) with $\mathrm{K}_{3} \mathrm{Fe}(\mathrm{CN})_{6}$ /sodium acetate $(\mathrm{NaOAc})$ as oxidant yielded shegansu $\mathrm{B}(3)$ as the major product peak $(65.2 \%$ ) and another peak (about 10\%) according to high-performance liquid chromatography (HPLC). Further investigation showed that the latter peak comprised two indane dimers, 4 and 5, 
which indicates that the reaction is amenable for the formation of indane dimers. To substantiate this hypothesis, studies on the oxidative coupling reaction of resveratrol employing the same oxidants were conducted, resulting in the isolation of five resveratrol indane dimers 6-10, and the benzofuran derivative resveratrol trans-dehydrodimer 11 (Figure 1). Among the dimers, 4, 6 and 7 are new indane dimers. This paper reports on the oxidative coupling of $\mathbf{1}$ and $\mathbf{2}$ in aqueous acetone with $\mathrm{K}_{3} \mathrm{Fe}(\mathrm{CN})_{6} / \mathrm{NaOAc}$ as oxidant, the isolation and structural identification of the products, and the discussion of the mechanisms of formation of all the products.
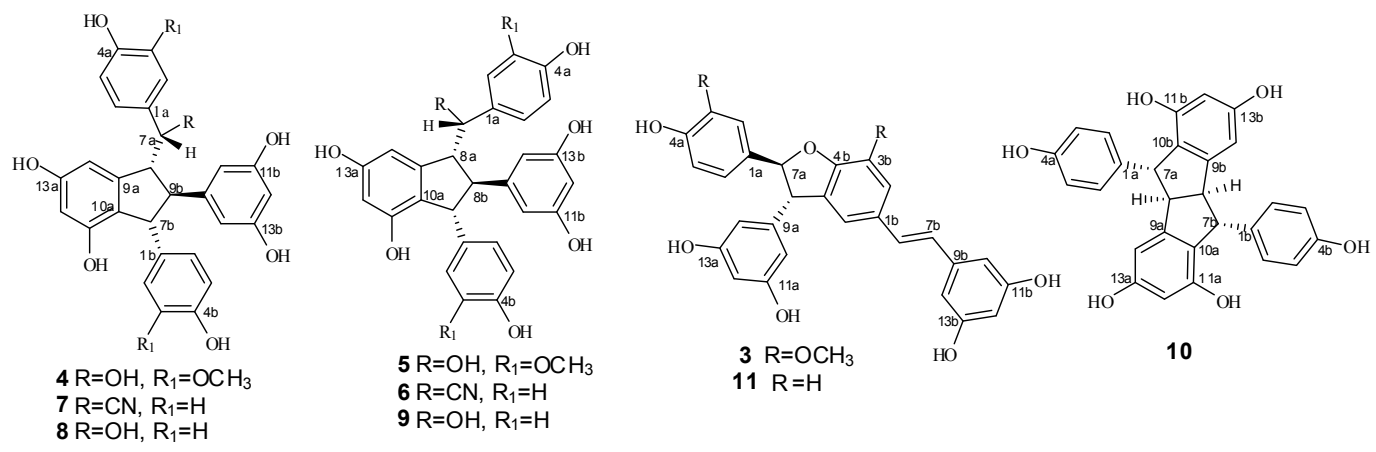

Figure 1. Structures of compounds 3-11.

\section{Results and Discussion}

\subsection{Treatment of $\mathbf{2}$ with Potassium Hexacyanoferrate (III)/Sodium Acetate}

As reported in a previous paper [13], the oxidative coupling reaction of 2 in aqueous acetone using $\mathrm{K}_{3} \mathrm{Fe}(\mathrm{CN})_{6} / \mathrm{NaOAc}$ as oxidant at room temperature generated a major product peak 3 in $65.2 \%$ yield and a peak of another product obtained in $10 \%$ yield with a retention time of $4.2 \mathrm{~min}$ in the HPLC chromatogram (Figure 2).

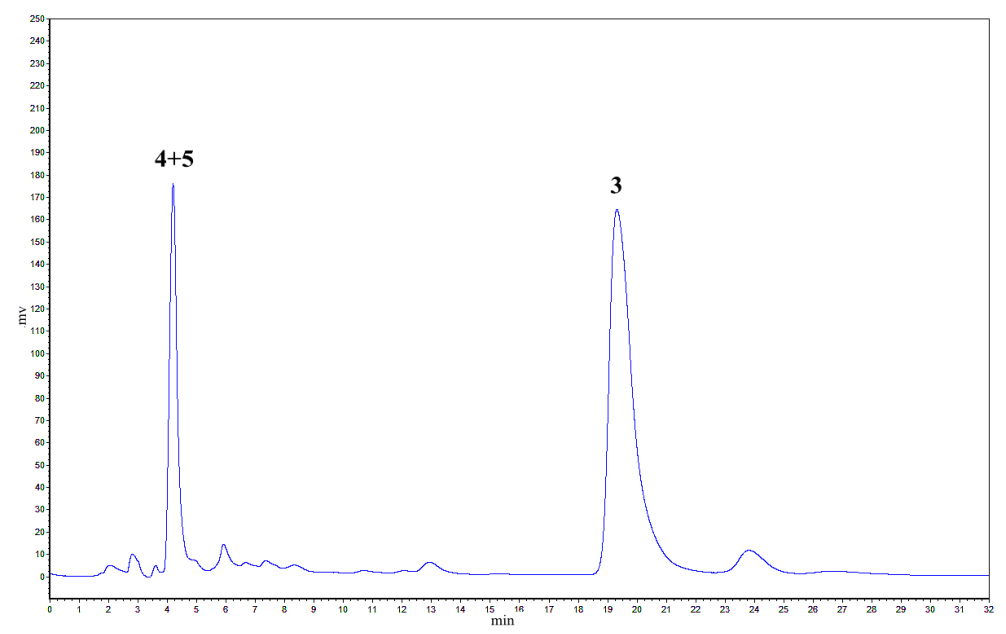

Figure 2. Analysis of isorhapontigenin oxidation products by $\mathrm{K}_{3} \mathrm{Fe}(\mathrm{CN})_{6} / \mathrm{NaOAc}\left(32 \% \mathrm{CH}_{3} \mathrm{CN} / \mathrm{H}_{2} \mathrm{O}\right.$, $\lambda=230 \mathrm{~nm}, 1 \mathrm{~mL} / \mathrm{min}$ ).

This finding indicates that the reaction mainly produced two types of products as compared with the complex products seen in the common oxidative coupling reactions of hydroxylstilbene [13-16]. Furthermore, several reports of $\mathrm{K}_{3} \mathrm{Fe}(\mathrm{CN})_{6}$ molecules catalyzing the oxidative coupling reaction of hydroxystilbene can be found in the literature [11,12]. However, to the best of our knowledge, a detailed investigation on this reaction, especially for the $\mathrm{K}_{3} \mathrm{Fe}(\mathrm{CN})_{6} / \mathrm{NaOAc}$ oxidant system, has yet to be reported. In this study, isorhapontigenin was treated with $\mathrm{K}_{3} \mathrm{Fe}(\mathrm{CN})_{6} / \mathrm{NaOAc}$ in aqueous 
acetone at room temperature, followed by silica gel column chromatography, preparative HPLC, and semi-preparative HPLC to obtain a major product 3 in $52.2 \%$ yield, as well as two indane dimers 4 and 5 (Figure 1) in $6.0 \%$ and $3.3 \%$ yield, respectively. Among these dimers, 5 possesses the same structure as the natural product gnetuhainin I [17], and compound 4, an isomer of 5, is a new isorhapontigenin dimer. These indane dimers were obtained for the first time by direct transformation from isorhapontigenin. The results imply that these reaction conditions which led to a total yield of about $10 \%$ for the indane dimers should be beneficial to the formation of carbon-carbon bonds.

\subsection{Treatment of $\mathbf{1}$ with Potassium Hexacyanoferrate (III)/Sodium Acetate}

To substantiate the above hypothesis, we conducted a further study on the oxidative coupling reaction of resveratrol catalyzed by $\mathrm{K}_{3} \mathrm{Fe}(\mathrm{CN})_{6} / \mathrm{NaOAc}$ in aqueous acetone under reflux for $60 \mathrm{~h}$. This approach was used because when resveratrol was treated at room temperature for one week, only small amounts of products were observed, and large amounts of unchanged resveratrol were recovered. Under the optimized conditions, two major products were observed on TLC plates, whereas other than the major products, several peaks ascribed to indane isomers of resveratrol dimer on the basis of previous results, appeared in the HPLC chromatogram (Figure 3). Therefore, by application of the above conditions, the oxidative coupling reaction of $1000 \mathrm{mg}$ resveratrol, combined with silica gel column chromatography (CC), preparative HPLC, and semi-preparative HPLC, led to the isolation of six resveratrol dimers: one major benzofuran product $\mathbf{1 1}$ (21.1\% yield) and five indane dimers 6 (4.9\% yield), 7 (5.9\%), 8 (1.3\%), 9 (2.1\%), and 10 (0.8\%, Figure 1). Among these dimers, 6 and $\mathbf{7}$ are new indane stilbene dimers that are substituted by a cyano group. Dimers 8, 9, 10, and $\mathbf{1 1}$ possess the same structures as the natural products leachianol $\mathrm{G}$, leachianol F, pallidol, and resveratrol trans-dehydrodimer. The total yield of about $15 \%$ for indane products indicates that the indane dimer is one of the major products in this reaction.

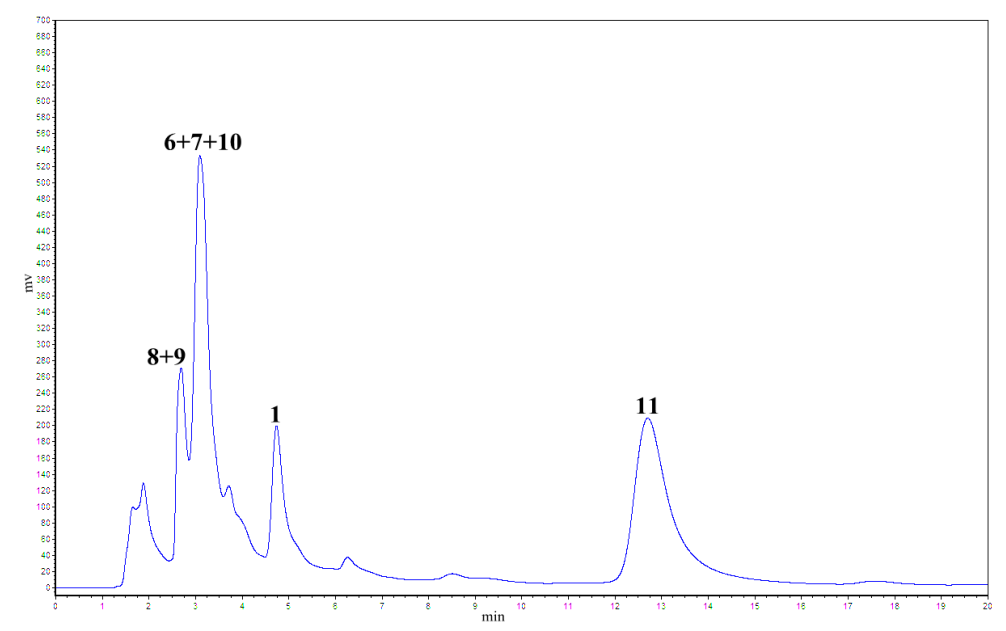

Figure 3. Analysis of resveratrol oxidation products by $\mathrm{K}_{3} \mathrm{Fe}(\mathrm{CN})_{6} / \mathrm{NaOAc}\left(52 \% \mathrm{MeOH} / \mathrm{H}_{2} \mathrm{O}\right.$, $\lambda=230 \mathrm{~nm}, 1 \mathrm{~mL} / \mathrm{min}$ ).

\subsection{Structural Identification of New Dimers}

Compound 4 was isolated as a brown amorphous powder. The corresponding negative ion HR-ESI-MS (Figure S8) peak at $m / z 531.1662[\mathrm{M}-\mathrm{H}]^{-}$(calcd. for $\mathrm{C}_{30} \mathrm{H}_{27} \mathrm{O}_{9}, 531.1661$ ) showed the molecular formula of $\mathrm{C}_{30} \mathrm{H}_{28} \mathrm{O}_{9}$, which together with the ${ }^{1} \mathrm{H}$ - and ${ }^{13} \mathrm{C}-\mathrm{NMR}$ spectral data, suggests that 4 should be an isorhapontigenin dimer. The IR spectrum (Figure S10) displays the presence of hydroxyls $\left(3360 \mathrm{~cm}^{-1}\right)$ and aromatic groups $\left(1605\right.$ and $\left.1516 \mathrm{~cm}^{-1}\right)$. The ${ }^{1} \mathrm{H}-\mathrm{NMR}$ spectrum (Figure S1, Table 1) shows two ABX systems for rings A1 and B1 at $\delta_{\mathrm{H}} 6.82(1 \mathrm{H}, \mathrm{d}, 1.8), 6.61(1 \mathrm{H}$, $\mathrm{d}, 7.8), 6.57(1 \mathrm{H}, \mathrm{dd}, 7.8,1.8)$, and $6.37(1 \mathrm{H}, \mathrm{d}, 1.8), 6.55(1 \mathrm{H}, \mathrm{d}, 8.4)$, and $6.30(1 \mathrm{H}, \mathrm{dd}, 8.4,1.8)$, one 
$\mathrm{AB}_{2}$ system at $\delta_{\mathrm{H}} 6.02(1 \mathrm{H}, \mathrm{t}, 2.4)$ and $6.03(2 \mathrm{H}, \mathrm{d}, 2.4)$ for ring B2, two meta-coupled proton signals at $\delta_{\mathrm{H}} 6.08(1 \mathrm{H}, \mathrm{d}, 1.8)$ and $6.07\left(1 \mathrm{H}\right.$, brs) for ring $\mathrm{A} 2$, four multi-coupled aliphatic protons at $\delta_{\mathrm{H}} 4.48$ $(1 \mathrm{H}, \mathrm{d}, 7.2), 4.08(1 \mathrm{H}, \mathrm{d}, 4.8), 3.49(1 \mathrm{H}, \mathrm{t}, 6.0)$, and $3.17(1 \mathrm{H}, \mathrm{t}, 5.4) \mathrm{ppm}$, and two methoxyl singlets at $\delta_{\mathrm{H}} 3.61(3 \mathrm{H}, \mathrm{s})$, and $3.65(3 \mathrm{H}, \mathrm{s})$. The ${ }^{13} \mathrm{C}-\mathrm{NMR}$ spectrum (Figure S2, Table 1$)$ of 4 reveals the presence of four aliphatic carbons at $\delta_{C} 78.0,61.8,60.0$, and $57.4 \mathrm{ppm}$, as well as 24 aromatic carbons and two methoxy carbons. The aliphatic carbon at $\delta_{C} 78.0$ is due to an alcohol carbon. This group of evidence indicates that compound 4 possesses a similar indane skeleton as $\mathbf{5}$, as reported in the literature [17]. In addition, downfield shifts of $\mathrm{H}-2 \mathrm{a}, \mathrm{H}-6 \mathrm{a}, \mathrm{H}-8 \mathrm{~b}$, and $\mathrm{H}-10(14) \mathrm{b}$ and the corresponding upfield shift of $\mathrm{H}-14 \mathrm{a}$ caused by the anisotropic effect of the aromatic ring in comparison to those of 5 proved that 4 should be an 7-epimer of 5 [18]. In the HMBC spectrum of 4 (Figure 4), the correlations among $\mathrm{H}-2 \mathrm{a}, \mathrm{H}-6 \mathrm{a}, \mathrm{H}-14 \mathrm{a}$ and C-7a, which is attached to the hydroxyl group, indicates that C-7a is excluded from the additional ring. The correlations between $\mathrm{H}-7 \mathrm{~b}, \mathrm{H}-8 \mathrm{~b}, \mathrm{H}-5 \mathrm{~b}$ and $\mathrm{C}-1 \mathrm{~b}$ verify that the $\mathrm{B} 1$ ring should be connected at $\mathrm{C}-7 \mathrm{~b}$. Comparison of the spectral data with those of 5 , as well as the analysis of COSY, HMBC and HSQC correlations (Figures S4-S6), determines the planar structure of 4 as shown in Figure 1. The stereochemistry of 4 was determined by analysis of NOESY spectrum (Figure S7 and Figure 4), in which strong NOEs between $\mathrm{H}-10(14) \mathrm{b}$ with $\mathrm{H}-7 \mathrm{~b}$ and $\mathrm{H}-8 \mathrm{a}$ suggests a trans orientation between $\mathrm{H}-7 \mathrm{~b}$ and $\mathrm{H}-8 \mathrm{~b}$ as well as between $\mathrm{H}-8 \mathrm{~b}$ and $\mathrm{H}-8 \mathrm{a}$. The NOE interactions between $\mathrm{H}-7 \mathrm{a}$ and $\mathrm{H}-8 \mathrm{~b}$ revealed a cis relationship of $\mathrm{H}-7 \mathrm{a}$ and $\mathrm{H}-8 \mathrm{~b}$. Accordingly, the structure of $\mathbf{4}$ was determined as shown in Figure 1.

Table 1. ${ }^{1} \mathrm{H}$ - and ${ }^{13} \mathrm{C}-\mathrm{NMR}$ spectroscopic data of 4 and $5 *$.

\begin{tabular}{|c|c|c|c|c|}
\hline \multirow{2}{*}{ Position } & \multicolumn{2}{|c|}{4} & \multicolumn{2}{|c|}{5} \\
\hline & $\delta_{C}$ & $\delta_{\mathbf{H}}$ & $\delta_{C}$ & $\delta_{\mathbf{H}}$ \\
\hline 1a & $135.5 \mathrm{~s}$ & & $136.5 \mathrm{~s}$ & \\
\hline $2 a$ & $112.4 \mathrm{~d}$ & $6.82(\mathrm{~d}, 1.8)$ & $112.4 \mathrm{~d}$ & $6.37(\mathrm{~d}, 1.8)$ \\
\hline $3 a$ & $148.5 \mathrm{~s}$ & & $148.7 \mathrm{~d}$ & \\
\hline $4 a$ & $146.9 \mathrm{~s}$ & & $146.7 \mathrm{~s}$ & \\
\hline $5 a$ & $115.3 \mathrm{~d}$ & $6.61(\mathrm{~d}, 7.8)$ & $115.74 d$ & $6.59(\mathrm{~d}, 7.8)$ \\
\hline $6 a$ & $121.1 \mathrm{~d}$ & $6.57(\mathrm{dd}, 7.8,1.8)$ & $120.94 d$ & $6.39(\mathrm{dd}, 7.8,1.8)$ \\
\hline $7 a$ & $78.0 \mathrm{~d}$ & $4.48(\mathrm{~d}, 7.2)$ & $78.7 \mathrm{~d}$ & $4.35(\mathrm{~d}, 9.0)$ \\
\hline $8 a$ & $61.8 \mathrm{~d}$ & $3.49(\mathrm{t}, 6.0)$ & $62.0 \mathrm{~d}$ & 3.29 (overlap) \\
\hline $9 a$ & $148.7 \mathrm{~s}$ & & $149.5 \mathrm{~s}$ & \\
\hline $10 \mathrm{a}$ & $123.9 \mathrm{~s}$ & & $123.0 \mathrm{~s}$ & \\
\hline $11 \mathrm{a}$ & $155.4 \mathrm{~s}$ & & $155.1 \mathrm{~s}$ & \\
\hline $12 a$ & 102.6 & $6.08(\mathrm{~d}, 1.8)$ & $102.6 \mathrm{~d}$ & $6.19(\mathrm{~d}, 1.8)$ \\
\hline $13 a$ & $158.8 \mathrm{~s}$ & & $159.2 \mathrm{~s}$ & \\
\hline $14 a$ & $106.0 \mathrm{~d}$ & 6.07 (br s) & $106.30 \mathrm{~d}$ & $6.58(\mathrm{~d}, 1.8)$ \\
\hline $1 b$ & $139.0 \mathrm{~s}$ & & $138.8 \mathrm{~s}$ & \\
\hline $2 b$ & $112.0 \mathrm{~d}$ & $6.37(\mathrm{~d}, 1.8)$ & $111.9 \mathrm{~d}$ & $6.49(\mathrm{~d}, 1.8)$ \\
\hline $3 b$ & $147.4 \mathrm{~s}$ & & $148.5 \mathrm{~s}$ & \\
\hline $4 b$ & $145.5 \mathrm{~s}$ & & $145.6 \mathrm{~s}$ & \\
\hline $5 b$ & $115.6 \mathrm{~d}$ & $6.55(\mathrm{~d}, 8.4)$ & $115.69 \mathrm{~d}$ & $6.62(\mathrm{~d}, 7.8)$ \\
\hline $6 b$ & $120.0 \mathrm{~d}$ & $6.30(\mathrm{dd}, 8.4,1.8)$ & $120.93 d$ & $6.35(\mathrm{dd}, 7.8,1.8)$ \\
\hline $7 \mathrm{~b}$ & $57.4 \mathrm{~d}$ & $4.08(\mathrm{~d}, 4.8)$ & $56.4 \mathrm{~d}$ & $4.14(\mathrm{~d}, 3.0)$ \\
\hline $8 b$ & $60.0 \mathrm{~d}$ & $3.17(t, 5.4)$ & $60.2 d$ & $2.74(t, 3.0)$ \\
\hline $9 b$ & $150.7 \mathrm{~s}$ & & $151.3 \mathrm{~s}$ & \\
\hline $10(14) b$ & $106.9 \mathrm{~d}$ & $6.03(\mathrm{~d}, 2.4)$ & $106.33 d$ & $5.75(\mathrm{~d}, 2.4)$ \\
\hline $11(13) \mathrm{b}$ & $159.4 \mathrm{~s}$ & & $159.3 \mathrm{~s}$ & \\
\hline $12 \mathrm{~b}$ & $101.3 \mathrm{~d}$ & $6.02(t, 2.4)$ & $101.2 \mathrm{~d}$ & $5.96(t, 2.4)$ \\
\hline $3 \mathrm{a}-\mathrm{OCH}_{3}$ & $56.3 q$ & $3.61(\mathrm{~s})$ & $56.3 q$ & $3.58(\mathrm{~s})$ \\
\hline $3 b-\mathrm{OCH}_{3}$ & $56.2 q$ & $3.65(\mathrm{~s})$ & $56.1 \mathrm{q}$ & $3.67(\mathrm{~s})$ \\
\hline
\end{tabular}

${ }^{*}$ Data $(\delta)$ were measured in $\mathrm{CD}_{3} \mathrm{OD}$ for ${ }^{1} \mathrm{H}$ at $600 \mathrm{MHz}$, and for ${ }^{13} \mathrm{C}$ at $150 \mathrm{MHz}$, The assignments were based on DEPT, ${ }^{1} \mathrm{H}^{-1} \mathrm{H}$ COSY, HSQC, HMBC, and NOESY experiments, respectively. 


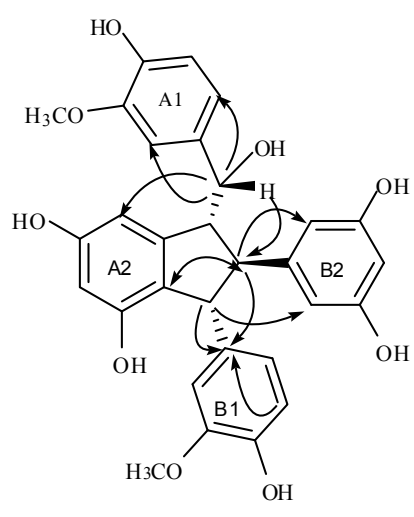

a

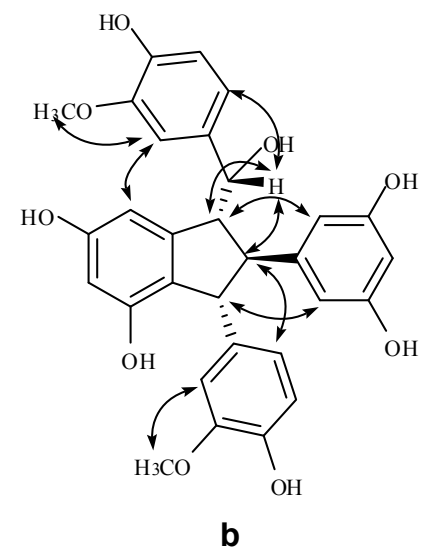

b

Figure 4. The significant $\operatorname{HMBC}(\mathbf{a})$ and NOESY (b) interactions of 4.

Compound 6 was obtained as a light gray amorphous powder. The corresponding positive ion HR-ESI-MS (Figure S17) peak at $\mathrm{m} / z 504.1409[\mathrm{M}+\mathrm{Na}]^{+}$(calcd. for $\mathrm{C}_{29} \mathrm{H}_{23} \mathrm{NO}_{6} \mathrm{Na}, 504.1418$ ) yield the molecular formula of $\mathrm{C}_{29} \mathrm{H}_{23} \mathrm{NO}_{6}$, which indicates that $\mathbf{6}$ should be a resveratrol dimer derivative. The IR spectrum (Figure S19) displayed the presence of hydroxyls $\left(3393.9 \mathrm{~cm}^{-1}\right)$, cyano group $\left(2248.6 \mathrm{~cm}^{-1}\right)$, and aromatic rings $\left(1610.6,1513.2,1468.4 \mathrm{~cm}^{-1}\right)$. The ${ }^{1} \mathrm{H}-\mathrm{NMR}$ spectrum (Table 2) shows two $\mathrm{A}_{2} \mathrm{~B}_{2}$ systems for ring $\mathrm{A} 1$ and $\mathrm{B} 1$ at $\delta_{\mathrm{H}} 6.89(2 \mathrm{H}, \mathrm{d}, 8.5), 6.79(2 \mathrm{H}, \mathrm{d}, 8.5), 6.87(2 \mathrm{H}, \mathrm{d}$, 8.5), and $6.76(2 \mathrm{H}, \mathrm{d}, 8.5)$, one $\mathrm{AB}_{2}$ system for ring $\mathrm{B} 2$ at $\delta_{\mathrm{H}} 5.96(2 \mathrm{H}, \mathrm{d}, 2.0)$ and $6.17(1 \mathrm{H}, \mathrm{t}, 2.0)$, two meta-coupled proton signals for ring $\mathrm{A} 2$ at $\delta_{\mathrm{H}} 6.38(1 \mathrm{H}, \mathrm{d}, 2.0)$ and $6.57(1 \mathrm{H}, \mathrm{d}, 2.0)$, and four multi-coupled aliphatic proton signals at $\delta_{\mathrm{H}} 4.28(1 \mathrm{H}, \mathrm{d}, 4.0), 3.76(1 \mathrm{H}, \mathrm{d}, 8.5), 3.52(1 \mathrm{H}, \mathrm{dd}, 8.5,4.0)$, and $3.01(1 \mathrm{H}, \mathrm{t}, 4.0) . \mathrm{C}_{29} \mathrm{H}_{23} \mathrm{NO}_{6}$, the quaternary carbon signal at $\delta_{\mathrm{C}} 120.33$ in the ${ }^{13} \mathrm{C}-\mathrm{NMR}$ data (Figure S12, Table 2) of $\mathbf{6}$ suggests the presence of a cyano group in the structure of $\mathbf{6}$. Accordingly, $\mathbf{6}$ was assumed to contain a leachianol $\mathrm{G}$ skeleton with a cyano group replacing a hydroxyl group [19]. In addition to a cyano group, 22 carbon signals in the ${ }^{13} \mathrm{C}-\mathrm{NMR}$ representing 28 carbons further support this hypothesis. In the HMBC spectrum (Figure S15, Figure 5), the interactions between H-7a and C-2(6)a, C-14a indicate that ring A1 is located at C-7; the interactions among H-8b, H-12b, and $\mathrm{C}-10(14) \mathrm{b}$ substantiate that ring B2 is connected at C-8b. Similarly, the correlations of the three proton signals of $\mathrm{H}-7 \mathrm{~b}, \mathrm{H}-8 \mathrm{~b}$, and $\mathrm{H}-3(5) \mathrm{b}$ with $\mathrm{C}-1 \mathrm{~b}$ reveal that ring $\mathrm{B} 1$ is connected at $\mathrm{C}-7 \mathrm{~b}$. Moreover, in the NOESY spectrum of 6 (Figure S16, Figure 5), the interactions between $\mathrm{H}-8 \mathrm{a}$ and $\mathrm{H}-7 \mathrm{~b}, \mathrm{H}-10(14) \mathrm{b}$, as well as between $\mathrm{H}-8 \mathrm{~b}$ and $\mathrm{H}-2(6) \mathrm{b}$ suggest a cis-configuration among $\mathrm{H}-8 \mathrm{a}, \mathrm{H}-7 \mathrm{~b}$ and ring $\mathrm{B} 2$. The interactions between $\mathrm{H}-7 \mathrm{a}$ and $\mathrm{H}-14 \mathrm{a}$ indicate that $\mathrm{H}-7 \mathrm{a}$ should be located near $\mathrm{H}-14 \mathrm{a}$, and that ring A1 is located near ring $B_{2}$. Therefore, the structure of 6 is characterized as shown in Figure 1.

Compound 7 was obtained as a light brown amorphous powder. The corresponding positive ion HR-ESI-MS (Figure S26) peak at $m / z 504.1431[\mathrm{M}+\mathrm{Na}]^{+}$(calcd. for $\mathrm{C}_{29} \mathrm{H}_{23} \mathrm{NO}_{6} \mathrm{Na}$, 504.1418) corresponds to the molecular formula of $\mathrm{C}_{29} \mathrm{H}_{23} \mathrm{NO}_{6}$. The IR spectrum (Figure S28) revealed the presence of hydroxyls $\left(3337.0 \mathrm{~cm}^{-1}\right)$, a cyano group $\left(2247.8 \mathrm{~cm}^{-1}\right)$, and aromatic rings $(1610.9,1513.5$, $1468.2 \mathrm{~cm}^{-1}$ ). The ${ }^{1} \mathrm{H}-\mathrm{NMR}$ spectrum (Figure S20, Table 2) shows two $\mathrm{A}_{2} \mathrm{~B}_{2}$ systems for rings $\mathrm{A} 1 \mathrm{and}$ $\mathrm{B} 1$, one $\mathrm{AB}_{2}$ system for ring $\mathrm{B} 2$, two meta-coupled proton signals for ring $\mathrm{A} 2$, and four aliphatic proton signals at $\delta_{\mathrm{H}} 4.27(1 \mathrm{H}, \mathrm{d}, 4.5), 3.96(1 \mathrm{H}, \mathrm{d}, 8.1), 3.58(1 \mathrm{H}, \mathrm{dd}, 8.1,4.5)$, and $3.26(1 \mathrm{H}, \mathrm{t}, 4.5)$. Together with the molecular formula $\mathrm{C}_{29} \mathrm{H}_{23} \mathrm{NO}_{6}$, the quaternary carbon signal at $\delta_{C} 120.33$ in the ${ }^{13} \mathrm{C}-\mathrm{NMR}$ data (Figure S21, Table 2) indicates the presence of a cyano group in the structure of 7 . In combination with the ${ }^{13} \mathrm{C}-\mathrm{NMR}$ spectral data and HMBC correlations (Figure S24, Figure 6), these data suggest that 7 should be an 7-epimer of 6 .

However, several exceptions in the ${ }^{1} \mathrm{H}-\mathrm{NMR}$ spectrum and a slight change in the chemical shift and multiplicity of certain signals were observed (Table 2). Owing to an anisotropic effect of the aromatic ring, the signals at $\delta_{\mathrm{H}} 7.06(2 \mathrm{H}, \mathrm{d}, 8.5)$ for $\mathrm{H}-2(6)$ a shifted slightly downfield whereas the signals at $\delta_{\mathrm{H}} 5.95(1 \mathrm{H}, \mathrm{brs})$ for $\mathrm{H}-14 \mathrm{a}$ shifted upfield in comparison with the spectrum of 6 . Besides, 
observation of the downfield shift of $\mathrm{H}-10(14) \mathrm{b}\left[\delta_{\mathrm{H}} 6.07(2 \mathrm{H}, \mathrm{d}, 2.0)\right]$ and $\mathrm{H}-8 \mathrm{~b}\left[\delta_{\mathrm{H}} 3.58(1 \mathrm{H}, \mathrm{dd}, 8.1\right.$, 4.5)] further supports the reversed position of the cyano group and ring A1 at C-7 compared with 6 .

The relative stereochemistry of 7 could be determined by analyzing the NOESY spectrum (Figure S25, Figure 6), in which the interactions between H-8a and H-7b, H-10(14)b suggest a cis configuration between $\mathrm{H}-8 \mathrm{a}, \mathrm{H}-\mathrm{7b}$ and ring B2. Together with the downfield shift of $\mathrm{H}-10(14) \mathrm{b}$ and upfield shift of $\mathrm{H}-14 \mathrm{a}$ in comparison to those of 6, the interaction between $\mathrm{H}-14 \mathrm{a}$ and $\mathrm{H}-2$ (6)a suggests that ring $\mathrm{A} 1$ must be located near ring $\mathrm{A} 2$, whereas the interaction between $\mathrm{H}-7 \mathrm{a}$ and $\mathrm{H}-8 \mathrm{~b}$ indicates that $\mathrm{H}-7 \mathrm{a}$ and $\mathrm{H}-8 \mathrm{~b}$ are situated in a cis-orientation. Therefore, the structure of $\mathbf{7}$ is characterized as shown in Figure 1.

Table 2. ${ }^{1} \mathrm{H}$ - and ${ }^{13} \mathrm{C}-\mathrm{NMR}$ spectroscopic data of 6 and 7 *.

\begin{tabular}{ccccc}
\hline \multirow{2}{*}{ Position } & \multicolumn{3}{c}{6} & \multicolumn{1}{c}{7} \\
\cline { 2 - 5 } & $\delta_{\mathrm{C}}$ & $\delta_{\mathrm{H}}$ & $\delta_{\mathrm{C}}$ & $\delta_{\mathbf{H}}$ \\
\hline $1 \mathrm{a}$ & $125.89 \mathrm{~s}$ & & $125.85 \mathrm{~s}$ & \\
$2(6) \mathrm{a}$ & $129.31 \mathrm{~d}$ & $6.89(2 \mathrm{H}, \mathrm{d}, 8.5)$ & $130.72 \mathrm{~d}$ & $7.06(2 \mathrm{H}, \mathrm{d}, 8.5)$ \\
$3(5) \mathrm{a}$ & $115.55 \mathrm{~d}$ & $6.79(2 \mathrm{H}, \mathrm{d}, 8.5)$ & $116.09 \mathrm{~d}$ & $6.74(2 \mathrm{H}, \mathrm{d}, 8.5)$ \\
$4 \mathrm{a}$ & $157.12 \mathrm{~s}$ & & $158.03 \mathrm{~s}$ & \\
$7 \mathrm{a}$ & $41.16 \mathrm{~d}$ & $3.76(1 \mathrm{H}, \mathrm{d}, 8.5)$ & $42.09 \mathrm{~d}$ & $3.96(1 \mathrm{H}, \mathrm{d}, 8.1)$ \\
$8 \mathrm{a}$ & $59.35 \mathrm{~d}$ & $3.01(1 \mathrm{H}, \mathrm{t}, 4.0)$ & $61.31 \mathrm{~d}$ & $3.26(1 \mathrm{H}, \mathrm{t}, 4.5)$ \\
$9 \mathrm{a}$ & $147.44 \mathrm{~s}$ & & $148.66 \mathrm{~s}$ & \\
$10 \mathrm{a}$ & $121.28 \mathrm{~s}$ & & $122.54 \mathrm{~s}$ & \\
$11 \mathrm{a}$ & $154.59 \mathrm{~s}$ & & $155.23 \mathrm{~s}$ & \\
$12 \mathrm{a}$ & $102.39 \mathrm{~d}$ & $6.38(1 \mathrm{H}, \mathrm{d}, 2.0)$ & $103.18 \mathrm{~d}$ & $6.30(1 \mathrm{H}, \mathrm{d}, 1.6)$ \\
$13 \mathrm{a}$ & $158.49 \mathrm{~s}$ & & $159.02 \mathrm{~s}$ & \\
$14 \mathrm{a}$ & $103.90 \mathrm{~d}$ & $6.57(1 \mathrm{H}, \mathrm{d}, 2.0)$ & $104.72 \mathrm{~d}$ & $5.95(1 \mathrm{H}, \mathrm{brs})$ \\
$1 \mathrm{~b}$ & $135.50 \mathrm{~s}$ & & $136.82 \mathrm{~s}$ & \\
$2(6) \mathrm{b}$ & $128.40 \mathrm{~d}$ & $6.87(2 \mathrm{H}, \mathrm{d}, 8.5)$ & $129.21 \mathrm{~d}$ & $6.84(2 \mathrm{H}, \mathrm{d}, 8.5)$ \\
$3(5) \mathrm{b}$ & $114.97 \mathrm{~d}$ & $6.76(2 \mathrm{H}, \mathrm{d}, 8.5)$ & $115.81 \mathrm{~d}$ & $6.71(2 \mathrm{H}, \mathrm{d}, 8.5)$ \\
$4 \mathrm{~b}$ & $155.72 \mathrm{~s}$ & & $156.51 \mathrm{~s}$ & \\
$7 \mathrm{~b}$ & $53.84 \mathrm{~d}$ & $4.28(1 \mathrm{H}, \mathrm{d}, 4.0)$ & $55.89 \mathrm{~d}$ & $4.27(1 \mathrm{H}, \mathrm{d}, 4.5)$ \\
$8 \mathrm{~b}$ & $56.70 \mathrm{~d}$ & $3.52(1 \mathrm{H}, \mathrm{dd}, 8.5,4.0)$ & $58.07 \mathrm{~d}$ & $3.58(1 \mathrm{H}, \mathrm{dd}, 8.1,4.5)$ \\
$9 \mathrm{~b}$ & $145.39 \mathrm{~s}$ & & $145.53 \mathrm{~s}$ & \\
$10(14) \mathrm{b}$ & $105.13 \mathrm{~d}$ & $5.96(2 \mathrm{H}, \mathrm{d}, 2.0)$ & $106.10 \mathrm{~d}$ & $6.07(2 \mathrm{H}, \mathrm{d}, 2.0)$ \\
$11(13) \mathrm{b}$ & $158.49 \mathrm{~s}$ & & $159.31 \mathrm{~s}$ & \\
$12 \mathrm{~b}$ & $100.75 \mathrm{~d}$ & $6.17(1 \mathrm{H}, \mathrm{t}, 2.0)$ & $101.42 \mathrm{~d}$ & $6.15(1 \mathrm{H}, \mathrm{t}, 2.0)$ \\
$\mathrm{CN}$ & $120.33 \mathrm{~s}$ & & $121.73 \mathrm{~s}$ & \\
\hline
\end{tabular}

${ }^{*}$ Data $(\delta)$ were measured in $\mathrm{CD}_{3} \mathrm{COCD}_{3}$ for ${ }^{1} \mathrm{H}$ at $500 \mathrm{MHz}$, and for ${ }^{13} \mathrm{C}$ at $125 \mathrm{MHz}$; The assignments were based on DEPT, HSQC, HMBC, and NOESY experiments, respectively.
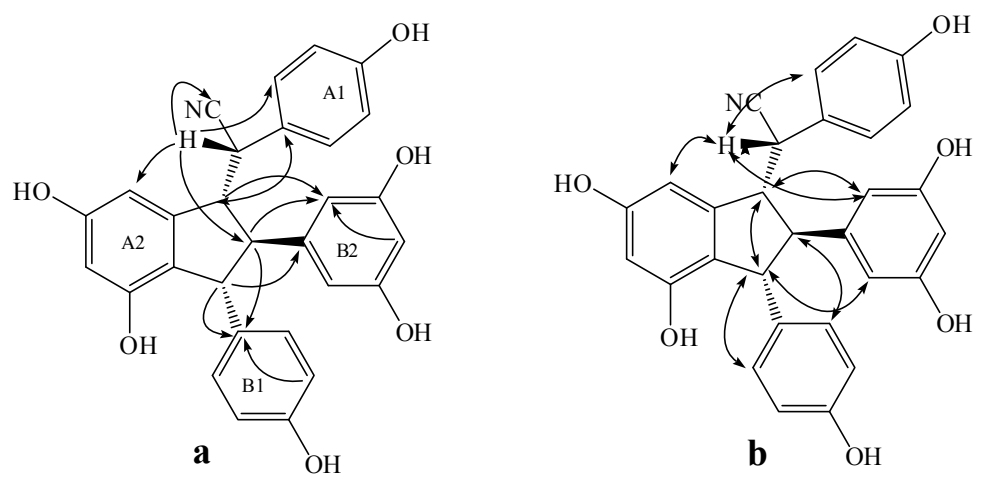

Figure 5. The key HMBC (a) and NOESY (b) correlations of 6. 

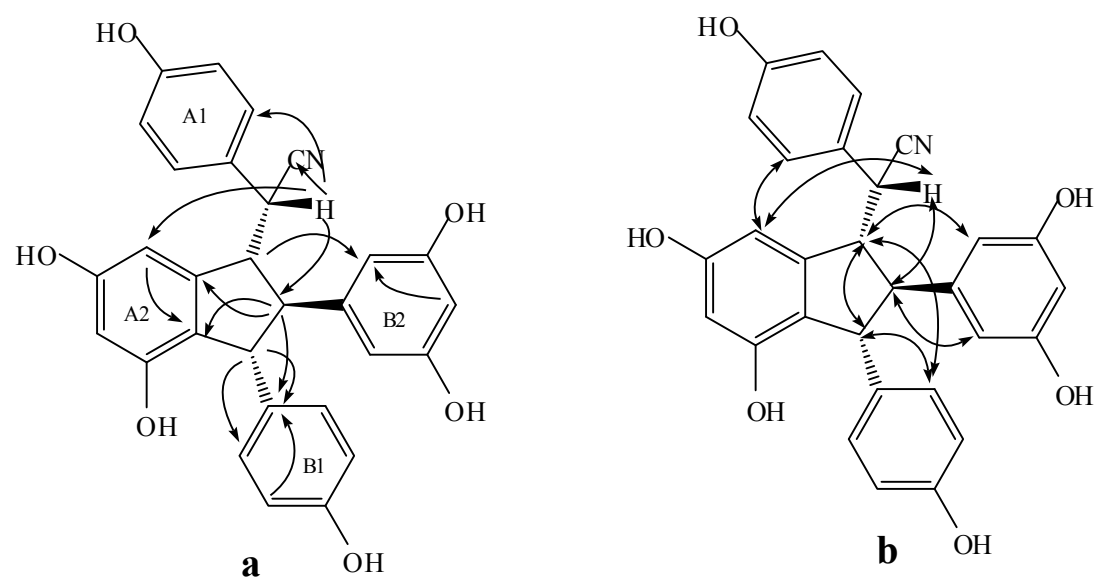

Figure 6. The key HMBC (a) and NOESY (b) correlations of $\mathbf{7 .}$

Known compounds 3, 5, 8, 9, 10, and 11 were identified as shegansu B [20], gnetuhainin I [17], leachianol G [21], leachianol F [21], pallidol [22], and resveratrol trans-dehydrodimer [23,24] by comparison of their physical and spectroscopic data with those reported in the literature. Product 5, which possesses an indane skeleton, was obtained for the first time by direct transformation from isorhapontigenin, and all these products would be rather difficult to obtain by common organic reactions. The transformation catalyzed by hexacyanoferrate (III)/sodium acetate was presumed to occur on the basis of a radical reaction. As a result, the obtained dimers should be racemates, which is consistent with the zero values of their optical rotations.

\subsection{Discussion of the Probable Coupling Reaction Mechanism}

On the basis of the aforementioned structures, the dimerization catalyzed by $\mathrm{K}_{3} \mathrm{Fe}(\mathrm{CN})_{6} / \mathrm{NaOAc}$ was presumed to be based on a radical reaction, induced by $\mathrm{K}_{3} \mathrm{Fe}(\mathrm{CN})_{6}$, whereby stilbene monomers 1 and 2 were dehydrogenated and rearranged to yield radicals $M_{4}, M_{5}, M_{8}$ and $M_{10}$ (Scheme 1) [11-14,25,26].<smiles>[R]C1=CC(=CC=c2ccc(=CC=Cc3cc(O)cc(O)c3)c([R])c2)C=CC1=O</smiles>

Scheme 1. Plausible radicals of $\mathbf{1}$ and 2.

The coupling of radicals $\mathrm{M}_{8}$ and $\mathrm{M}_{5}$ then occurred successively, followed by tautomeric rearrangement and intramolecular nucleophilic attack to the intermediate quinone [A], yielding the dihydrofunan dimers 3 and 11, respectively (Scheme 2). Meanwhile, the coupling of two $\mathrm{M}_{8}$ radicals, followed by intramolecular cyclization, generates intermediate quinone [M]. The difference in the ultimate products is apparently due to the difference in the position and reagent of the nucleophilic attack (Scheme 3). In the case of path a, intermolecular nucleophilic attack to the intermediate quinone [M] of a cyano anion $\left(\mathrm{CN}^{-}\right)$produced 7 and its isomer $\mathbf{6}$. In the case of path $\mathbf{b}$, intermolecular nucleophilic attack to the intermediate quinone of a water molecule produced 4,8 and their isomers 
5, 9. In the case of path $c$, the second intramolecular nucleophilic attack to the intermediate quinone $[\mathrm{M}]$ yielded 10. Evidently, all reactions mentioned above should be carried out concertedly. In general, free radical reaction is not stereoselective. In the course of nucleophilic attack reaction, the chances of attack to Re or Si face of intermediates are equal. Therefore, all products are found to be enantiomer pairs.
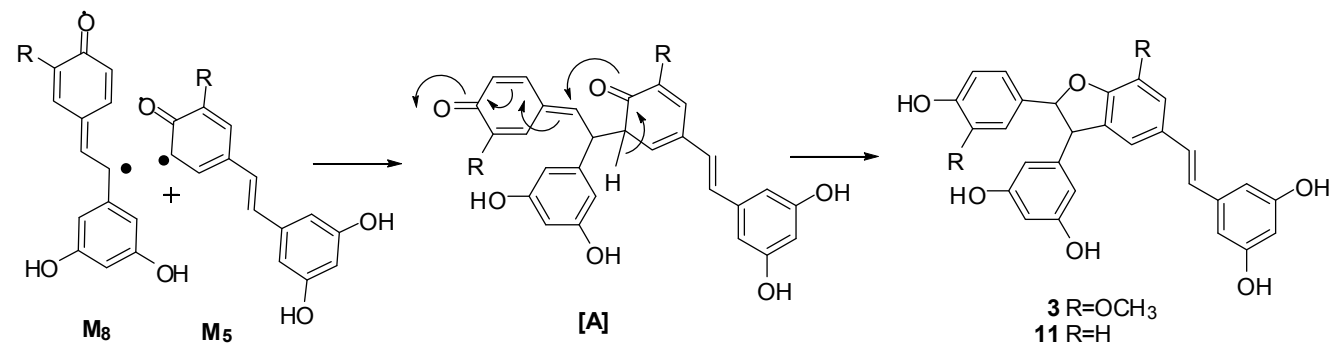

Scheme 2. Proposed coupling mechanism of compounds 3 and $\mathbf{1 1 .}$

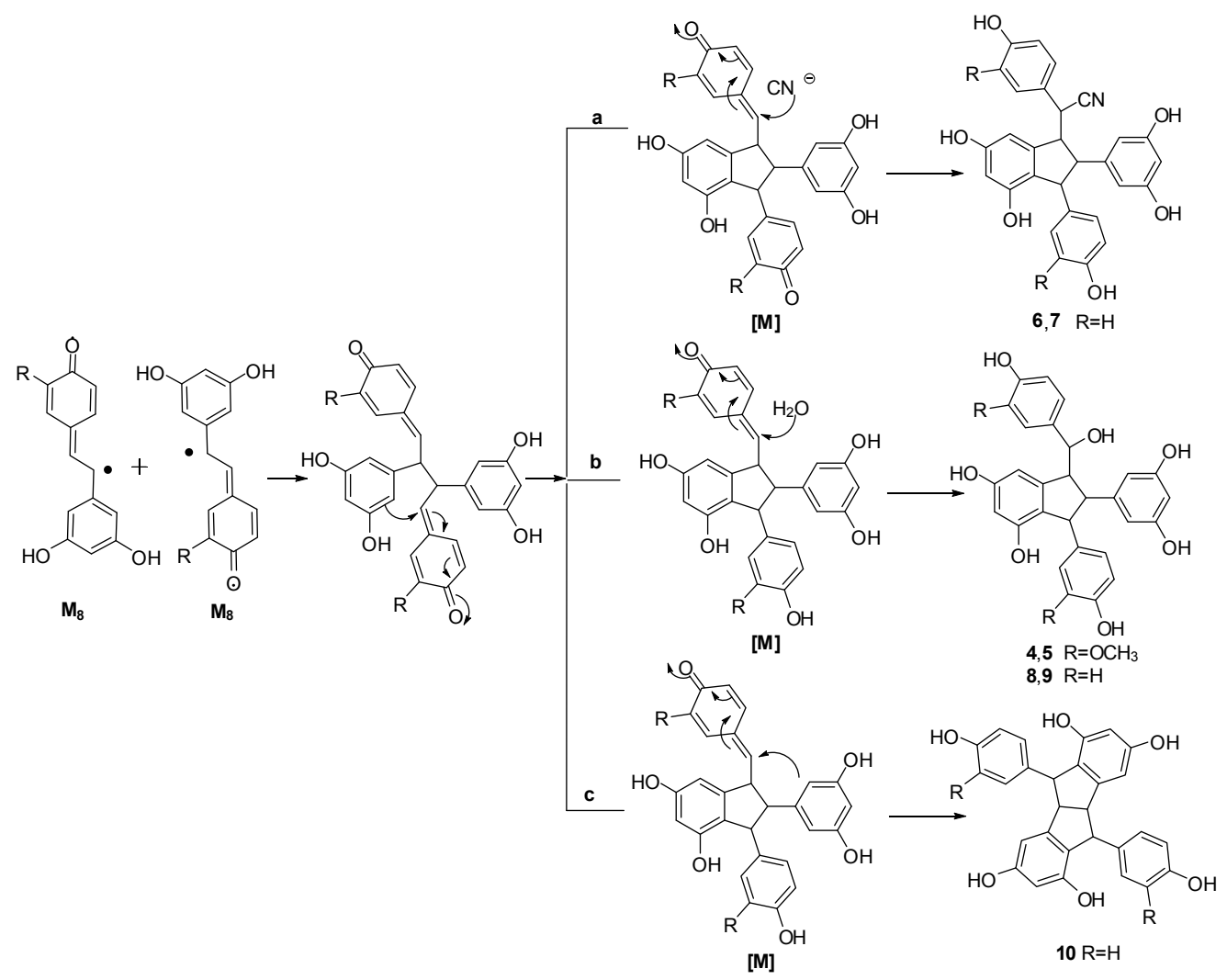

Scheme 3. Proposed coupling mechanism of compounds 4-10.

Moreover, the comparatively high yield of 6 and 7 results from the high nucleophilicity of the cyano anion, and the low yield of $\mathbf{1 0}$ results from the low nucleophilicity of the phenyl group. The dimeric structures indicate that, during the long reaction time, the oxidation reactions of hydroxystilbene through $\mathrm{K}_{3} \mathrm{Fe}(\mathrm{CN})_{6} / \mathrm{NaOAc}$ in aqueous acetone, mainly generate $\mathrm{M}_{5}$ and $\mathrm{M}_{8}$. Product coupling involving $\mathrm{M}_{4}$ and $\mathrm{M}_{10}$ was not detected in the course of the reaction. The sterically less hindered radical $\mathrm{M}_{5}$ would be easily involved in the reaction, possibly accounting for the higher yield of benzofuran products 3 and 11. However, an appropriate account for the distinction of reactivity cannot be proposed based only on this evidence. 


\section{Experimental Section}

\subsection{Materials and Instrumentation}

Optical rotations were measured on a P2000 polarimeter (JASCO, Tokyo, Japan). UV spectra were obtained on a JASCO P650 spectrometer. IR spectra were recorded on a Nicolet 5700 FT-IR microscope instrument (FT-IR microscope transmission, Thermo Electron Corporation, Madison, WI, USA). 1D and 2D NMR spectra were acquired at 500 or $600 \mathrm{MHz}$ for ${ }^{1} \mathrm{H}$ and 125 or $150 \mathrm{MHz}$ for ${ }^{13} \mathrm{C}$, respectively, on INOVA $500 \mathrm{MHz}$ (Varian, Inc., Palo Alto, CA, USA), or Bruker AVANCE III HD $600 \mathrm{MHz}$ spectrometers (Bruker Corporation, Karlsruhe, Germany), in acetone- $d_{6}$ or methanol- $d_{4}$, with the solvent peaks as references. ESI-MS and HR-ESI-MS data were measured using an AccuToFCS JMST100CS spectrometer (Agilent Technologies, Ltd., Santa Clara, CA, USA). Column chromatography (CC) was performed with silica gel (200-300 mesh, Qingdao Marine Chemical Inc., Qingdao, China). HPLC separation was performed on an instrument consisting of a Waters 515 pump and a Waters 2487 dual $\lambda$ absorbance detector (Waters Corporation, Milford, MA, USA) with a YMC semi-preparative column $(250 \mathrm{~mm} \times 10 \mathrm{~mm}$ ID) packed with C18 $(5 \mu \mathrm{M})$. TLC was carried out with glass precoated silica gel GF254 plates (Qingdao Marine Chemical, Inc.). Spots were visualized under UV light or by spraying with $7 \% \mathrm{H}_{2} \mathrm{SO}_{4}$ in $95 \% \mathrm{EtOH}$ followed by heating.

\subsection{Treatment of Isorhapontigenin with Potassium Hexacyanoferrate (III)/Sodium Acetate.}

To a solution of $(E)$-isorhapontigenin $(2,100 \mathrm{mg}, 0.388 \mathrm{mmol})$ in acetone cooled to $0{ }^{\circ} \mathrm{C}$ in an ice bath, a mixed solution of $\mathrm{K}_{3} \mathrm{Fe}(\mathrm{CN})_{6}(150 \mathrm{mg}, 0.4559 \mathrm{mmol})$ and $\mathrm{NaOAc}(140 \mathrm{mg}, 1.7073 \mathrm{mmol})$ in $25 \mathrm{~mL}$ of water was added under stirring. The reactant was stirred at $0{ }^{\circ} \mathrm{C}$ for $1 \mathrm{~h}$ under a $\mathrm{N}_{2}$ atmosphere, and subsequently stirred for another 15 days at room temperature. The reaction mixture was extracted with ethyl acetate and water, the organic layer was washed with brine, water and dried over anhydrous $\mathrm{Na}_{2} \mathrm{SO}_{4}$ for $24 \mathrm{~h}$. Then it was concentrated in vacuo to yield a residue that was subjected to silica gel column chromatography eluting with $\mathrm{CHCl}_{3}-\mathrm{MeOH}(10: 1, v / v)$ to give 3 $(52.1 \mathrm{mg}, 52.2 \%)$ and fraction Fr-1 (14.0 mg). Fr-1 was subsequently subjected to semi-preparative Rp-18 HPLC (column, Rp-18, $250 \mathrm{~mm} \times 10 \mathrm{~mm}$ I.D., $5 \mu \mathrm{m}$, YMC) eluting with acetonitrile in water $(25: 75, v / v)$ to yield compounds $4(6.2 \mathrm{mg}, 6.0 \%)$ and $5(3.4 \mathrm{mg}, 3.3 \%)$, respectively.

Compound 4: brown amorphous powder; $[\alpha]_{\mathrm{D}}^{20} 0(c=0.66, \mathrm{MeOH}) ; \mathrm{UV}(\mathrm{MeOH}) \lambda_{\max }(\log \varepsilon): 229$ (sh, 4.47), 281 (4.08) nm; IR (film) $v_{\max }: 3360,2973,1605,1516,1464,1344,1276,1151,1127,1032,1004$, 841, 822, $699 \mathrm{~cm}^{-1} ;{ }^{1} \mathrm{H}-\mathrm{NMR}\left(600 \mathrm{MHz}, \mathrm{CD}_{3} \mathrm{OD}\right)$ and ${ }^{13} \mathrm{C}-\mathrm{NMR}\left(150 \mathrm{MHz}, \mathrm{CD}_{3} \mathrm{OD}\right)$, see Table 1; ESI-MS m/z: $555.3[\mathrm{M}+\mathrm{Na}]^{+}, 571.2\left[\mathrm{M}+\mathrm{K}^{+}, 531.2[\mathrm{M}-\mathrm{H}]^{-}, 567.2[\mathrm{M}+\mathrm{Cl}]^{-} ; \mathrm{HR}-\mathrm{ESI}-\mathrm{MS} \mathrm{m} / z\right.$ : $531.1662[\mathrm{M}-\mathrm{H}]^{-}$(cacld. for $\mathrm{C}_{30} \mathrm{H}_{27} \mathrm{O}_{9}, 531.1661$ ).

Gnetuhainin I (5): brown amorphous powder; $[\alpha]_{\mathrm{D}}^{20} 0(c=0.70, \mathrm{MeOH}) ;{ }^{1} \mathrm{H}-\mathrm{NMR}\left(600 \mathrm{MHz}, \mathrm{CD}_{3} \mathrm{OD}\right)$ and ${ }^{13} \mathrm{C}$-NMR $\left(150 \mathrm{MHz}, \mathrm{CD}_{3} \mathrm{OD}\right)$, see Table 1; ESI-MS $\mathrm{m} / z: 555.2[\mathrm{M}+\mathrm{Na}]^{+}, 571.2\left[\mathrm{M}+\mathrm{K}^{+}\right.$, $531.2[\mathrm{M}-\mathrm{H}]^{-}, 567.2\left[\mathrm{M}+\mathrm{Cl}^{-}\right.$; HR-ESI-MS m/z: $531.1661[\mathrm{M}-\mathrm{H}]^{-}$(cacld. for $\mathrm{C}_{30} \mathrm{H}_{27} \mathrm{O}_{9}, 531.1661$ ).

\subsection{Treatment of Resveratrol with Potassium Hexacyanoferrate (III)/Sodium Acetate}

To a solution of resveratrol $(\mathbf{1}, 1000 \mathrm{mg})$ in acetone $(100 \mathrm{ml})$, a mixed solution of $\mathrm{K}_{3} \mathrm{Fe}(\mathrm{CN})_{6}$ $(2885.0 \mathrm{mg})$ and $\mathrm{NaOAc}(2660.0 \mathrm{mg})$ in water $(125 \mathrm{~mL})$ was added under stirring. The reactant was refluxed for $35 \mathrm{~h}$, after removal of the acetone under reduced pressure, the solution was extracted with ethyl acetate $(100 \mathrm{~mL} \times 3)$, the organic layer was washed with brine, water and dried over anhydrous $\mathrm{Na}_{2} \mathrm{SO}_{4}$ for $24 \mathrm{~h}$. The solution was concentrated in vacuo to yield a reaction mixture that was subjected to a silica gel (200-300 mesh, $12.5 \mathrm{~g})$ column and eluted with a gradient of increasing $\mathrm{MeOH}$ in $\mathrm{CHCl}_{3}(15: 1,10: 1,6: 1,4: 1,2: 1,1: 1, v / v)$ to provide seven fractions, namely, FNR-A FNR-G. FNR-B (102.1 mg) was unchanged resveratrol, and FNR-C was the main product 11 (187.6 mg, 21.1\%). $45 \mathrm{mg}$ FNR-D (132.2 mg) was then separated by semi-preparative Rp-HPLC (column, Rp-18, $250 \times 10 \mathrm{~mm}, 5 \mu \mathrm{m})$ eluted using methanol/water $(35: 65, v / v)$ to afford $6(15.8 \mathrm{mg}, 4.9 \%)$ and 7 
(17.7 $\mathrm{mg}, 5.9 \%)$. FNR-F (110.7 mg) was dealt with in the same manner to give 8 (12.1 $\mathrm{mg}, 1.3 \%), 9$ (19.5 $\mathrm{mg}, 2.1 \%)$ and $10(7.1 \mathrm{mg}, 0.8 \%)$, respectively.

Compound 6: a light gray amorphous powder. $[\alpha]_{\mathrm{D}}^{20} 0(c=0.33, \mathrm{MeOH}) ; \mathrm{UV}(\mathrm{MeOH}) \lambda_{\max }(\log \varepsilon): 206$ (4.48), 228 (4.21, sh), 282 (3.59) nm; IR (film) $v_{\max }$ : 3393.9, 2920.3, 2849.7, 2248.6, 1610.6, 1513.2, 1468.4, 1344.1, 1247.6, 1157.3, 1003.3, $835.7 \mathrm{~cm}^{-1} ;{ }^{1} \mathrm{H}-\mathrm{NMR}\left(500 \mathrm{MHz}\right.$ in acetone- $\left.d_{6}\right)$ and ${ }^{13} \mathrm{C}-\mathrm{NMR}(125 \mathrm{MHz}$ in acetone- $\left.d_{6}\right)$, see Table 2; (+)-ESI-MS $m / z: 482[\mathrm{M}+\mathrm{H}]^{+}, 504[\mathrm{M}+\mathrm{Na}]^{+}, 520[\mathrm{M}+\mathrm{K}]^{+}$; HR-ESI-MS $m / z: 504.1409[\mathrm{M}+\mathrm{Na}]^{+}$(cacld. for $\mathrm{C}_{29} \mathrm{H}_{23} \mathrm{NO}_{6} \mathrm{Na}, 504.1418$ ).

Compound 7: a light brown amorphous powder. $[\alpha]_{\mathrm{D}}^{20} 0(c=0.66, \mathrm{MeOH}) ; \mathrm{UV}(\mathrm{MeOH}) \lambda_{\max }(\log \varepsilon)$ : 204 (4.55), 230 (4.22, sh), 283 (3.70), nm; IR (film) $v_{\max }$ : 3337.0, 2916.6, 2850.1, 1610.9, 1513.5, 1468.2, $1342.0,1247.8,1155.6,1006.9,834.0 \mathrm{~cm}^{-1} ;{ }^{1} \mathrm{H}-\mathrm{NMR}\left(500 \mathrm{MHz}\right.$ in acetone- $\left.d_{6}\right)$ and ${ }^{13} \mathrm{C}-\mathrm{NMR}(125 \mathrm{MHz}$ in acetone- $\left.d_{6}\right)$, see Table 2; (+)-ESI-MS $m / z: 482[\mathrm{M}+\mathrm{H}]^{+}, 504[\mathrm{M}+\mathrm{Na}]^{+}, 520[\mathrm{M}+\mathrm{K}]^{+}$; HR-ESI-MS $m / z: 504.1431[\mathrm{M}+\mathrm{Na}]^{+}$(cacld. for $\mathrm{C}_{29} \mathrm{H}_{23} \mathrm{NO}_{6} \mathrm{Na}, 504.1418$ ).

Leachianol G (8): a brown amorphous powder. $[\alpha]_{\mathrm{D}}^{20} 0(c=1.05, \mathrm{MeOH}) ;{ }^{1} \mathrm{H}-\mathrm{NMR}(500 \mathrm{MHz}$ in acetone- $\left.d_{6}\right)$ data: $7.07(2 \mathrm{H}, \mathrm{d}, 8.5, \mathrm{H}-2(6) \mathrm{a}), 6.73(2 \mathrm{H}, \mathrm{d}, 8.5, \mathrm{H}-3(5) \mathrm{a}), 4.45(1 \mathrm{H}, \mathrm{d}, 8.2, \mathrm{H}-7 \mathrm{a}), 3.38$ $(1 \mathrm{H}, \mathrm{dd}, 8.2,3.5, \mathrm{H}-8 \mathrm{a}), 6.22(1 \mathrm{H}, \mathrm{d}, 2.0, \mathrm{H}-12 \mathrm{a}), 5.71(1 \mathrm{H}, \mathrm{d}, 2.0, \mathrm{H}-14 \mathrm{a}), 6.87$ (2H, d, 8.5, H-2(6)b), $6.71(2 \mathrm{H}, \mathrm{d}, 8.5, \mathrm{H}-3(5) \mathrm{b}), 4.27(1 \mathrm{H}, \mathrm{d}, 3.5, \mathrm{H}-7 \mathrm{~b}), 3.50(1 \mathrm{H}, \mathrm{t}, 3.5, \mathrm{H}-8 \mathrm{~b}), 6.14(2 \mathrm{H}, \mathrm{d}, 1.5, \mathrm{H}-10(14) \mathrm{b})$, $6.16(1 \mathrm{H}, \mathrm{t}, 1.5, \mathrm{H}-12 \mathrm{~b}) .{ }^{13} \mathrm{C}-\mathrm{NMR}\left(125 \mathrm{MHz}\right.$ in acetone- $\left.d_{6}\right)$ : $135.81 \mathrm{~s}$ (C-1a), $129.48 \mathrm{~d}(\mathrm{C}-2(6) \mathrm{a}), 115.18 \mathrm{~d}$ (C-3(5)a), 157.23s (C-4a), 77.25d (C-7a), 62.69d (C-8a), 147.38s (C-9a), 123.04s (C-10a), 154.84s (C-11a), 102.17d (C-12a), 158.49s (C-13a), 105.55d (C-14a), 138.09s (C-1b), 129.31d (C-2(6)b), 115.55d (C-3(5)b), 156.18s (C-4b), 55.93d (C-7b), 59.04d (C-8b), 151.63s (C-9b), 106.07d (C-10(14)b), 159.21s (C-11(13)b), 100.87d (C-12b). (+)-ESI-MS m/z: $473[\mathrm{M}+\mathrm{H}]^{+}, 495[\mathrm{M}+\mathrm{Na}]^{+}, 511[\mathrm{M}+\mathrm{K}]^{+}$; HR-ESI-MS m/z: $495.1419[\mathrm{M}+\mathrm{Na}]^{+}$(cacld. for $\mathrm{C}_{28} \mathrm{H}_{24} \mathrm{O}_{7} \mathrm{Na}, 495.1414$ ).

Leachianol $F(9)$ : a brown amorphous powder. $[\alpha]_{\mathrm{D}}^{20} 0(c=1.05, \mathrm{MeOH}) ;{ }^{1} \mathrm{H}-\mathrm{NMR}(500 \mathrm{MHz}$ in acetone- $\left.d_{6}\right)$ data: $6.86(2 \mathrm{H}, \mathrm{d}, 8.5, \mathrm{H}-2(6) \mathrm{a}), 6.68(2 \mathrm{H}, \mathrm{d}, 8.5, \mathrm{H}-3(5) \mathrm{a}), 4.46(1 \mathrm{H}, \mathrm{d}, 8.0, \mathrm{H}-7 \mathrm{a}), 3.37(1 \mathrm{H}$, $\mathrm{dd}, 8.0,3.5, \mathrm{H}-8 \mathrm{a}), 6.32(1 \mathrm{H}, \mathrm{d}, 1.5, \mathrm{H}-12 \mathrm{a}), 6.59(1 \mathrm{H}, \mathrm{d}, 1.5, \mathrm{H}-14 \mathrm{a}), 6.85(2 \mathrm{H}, \mathrm{d}, 8.5, \mathrm{H}-2(6) \mathrm{b}), 6.74(2 \mathrm{H}$, d, 8.5, H-3(5)b), 4.24 (1H, d, 3.5, H-7b), 2.95 (1H, t, 3.5, H-8b), $5.93(2 \mathrm{H}, \mathrm{d}, 2.0, \mathrm{H}-10(14 \mathrm{~b}), 6.13(1 \mathrm{H}, \mathrm{t}, 2.0$, $\mathrm{H}-12 \mathrm{~b}), 4.01(1 \mathrm{H}, \mathrm{d}, 3.5,7-\mathrm{OH}) .{ }^{13} \mathrm{C}-\mathrm{NMR}\left(125 \mathrm{MHz}\right.$ in acetone- $\left.\mathrm{d}_{6}\right): 136.28 \mathrm{~s}(\mathrm{C}-1 \mathrm{a}), 128.87 \mathrm{~d}(\mathrm{C}-2(6) \mathrm{a})$, 115.34d (C-3(5)a), 156.26s (C-4a), 76.58d (C-7a), 61.91d (C-8a), 148.84s (C-9a), 122.46s (C-10a), 154.96s (C-11a), 102.19d (C-12a), 158.75s (C-13a), 106.12d (C-14a), 137.46s (C-1b), 129.35d (C-2(6)b), 115.51d (C-3(5)b), 157.06s (C-4b), 55.61d (C-7b), 59.47d (C-8b), 150.75s (C-9b), 105.90d (C-10(14)b), 159.14s (C-11(13)b), 100.99d (C-12b). (+)-ESI-MS $m / z: 472[\mathrm{M}]^{+}, 495[\mathrm{M}+\mathrm{Na}]^{+}, 511[\mathrm{M}+\mathrm{K}]^{+} ;$HR-ESI-MS $m / z$ : $495.1425[\mathrm{M}+\mathrm{Na}]^{+}$(cacld. for $\mathrm{C}_{28} \mathrm{H}_{24} \mathrm{O}_{7} \mathrm{Na}, 495.1414$ ).

Pallidol (10): a brown amorphous powder. $[\alpha]_{\mathrm{D}}^{20} 0(c=1.05, \mathrm{MeOH}) ;{ }^{1} \mathrm{H}-\mathrm{NMR}\left(500 \mathrm{MHz}\right.$ in acetone- $\left.d_{6}\right)$ 8: 6.99 (2H, d, 8.5, H-2(6)a), 6.71 (2H, d, 8.5, H-3(5)a), 4.58 (1H, s, H-7a), $3.82(1 \mathrm{H}, \mathrm{s}, \mathrm{H}-8 \mathrm{a}), 6.20(1 \mathrm{H}$, $\mathrm{d}, 1.7, \mathrm{H}-10 \mathrm{a}), 6.63(1 \mathrm{H}, \mathrm{d}, 1.7, \mathrm{H}-10 \mathrm{a}), 3.32(1 \mathrm{H}, \mathrm{s}, \mathrm{OH}) ;{ }^{13} \mathrm{C}-\mathrm{NMR}\left(125 \mathrm{MHz}\right.$ in acetone- $\left.d_{6}\right) \delta: 137.74 \mathrm{~s}$ (C-1a), 129.05d (C-2(6)a), 115.74d (C-3(5)a), 159.27s (C-4a), 60.52d (C-7a), 53.97d (C-8a), 123.19 (C-9a), 102.35s (C-10a), 155.24s (C-11a), 103.28d (C-12a), 156.27s (C-13a), 150.53d (C-14a). (+)-ESI-MS m/z: $455[\mathrm{M}+\mathrm{H}]^{+}, 477[\mathrm{M}+\mathrm{Na}]^{+}, 493[\mathrm{M}+\mathrm{K}]^{+}$.

Resveratrol trans-dehydrodimer (11): a brown amorphous powder. ${ }^{1} \mathrm{H}-\mathrm{NMR}\left(500 \mathrm{MHz}\right.$ in acetone- $\left.d_{6}\right)$,

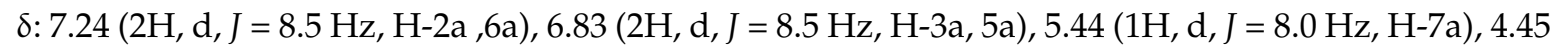
$(1 \mathrm{H}, \mathrm{d}, J=8.0 \mathrm{~Hz}, \mathrm{H}-8 \mathrm{a}), 6.18(2 \mathrm{H}, \mathrm{d}, J=2.0 \mathrm{~Hz}, \mathrm{H}-10 \mathrm{a}, 14 \mathrm{a}), 6.27(1 \mathrm{H}, \mathrm{t}, J=2.0 \mathrm{~Hz}, \mathrm{H}-12 \mathrm{a}), 7.25(1 \mathrm{H}$, brs, H-2b), $6.87(1 \mathrm{H}, \mathrm{d}, J=8.5 \mathrm{~Hz}, \mathrm{H}-5 \mathrm{~b}), 7.42(1 \mathrm{H}, \mathrm{dd}, J=8.5 \mathrm{~Hz}, 2.0, \mathrm{H}-6 \mathrm{~b}), 7.04(1 \mathrm{H}, \mathrm{d}, J=16.5 \mathrm{~Hz}$, $\mathrm{H}-7 \mathrm{~b}), 6.89(1 \mathrm{H}, \mathrm{d}, J=16.5 \mathrm{~Hz}, \mathrm{H}-8 \mathrm{~b}), 6.53(2 \mathrm{H}, \mathrm{d}, J=2.0 \mathrm{~Hz}, \mathrm{H}-10 \mathrm{~b}, 14 \mathrm{~b}), 6.27$ (1H, t, J = 2.0 Hz, H-12b); ${ }^{13} \mathrm{C}-\mathrm{NMR}\left(125 \mathrm{MHz}\right.$ in acetone- $\mathrm{d}_{6}$ ) $\delta: 131.71$ (C-1a), 128.57 (C-2a, 6a), 116.08 (C-3a, 5a), 158.33 (C-4a), 94.03 (C-7a), 57.80 (C-8a), 145.21 (C-9a), 107.33 (C-10a), 159.66 (C-11a), 102.24 (C-12a), 159.66 (C-13a), 107.33 (C-14a), 132.10 (C-1b), 123.90 (C-2b), 132.52 (C-3b), 160.60 (C-4b), 110.12 (C-5b), 128.61 (C-6b), 129.09 (C-7b), 127.19 (C-8b), 140.76 (C-9b), 105.63 (C-10b,14b), 159.45 (C-11b,13b), 102.57 (C-12b); (+) ESI $m / z: 455[\mathrm{M}+\mathrm{H}]^{+}, 477[\mathrm{M}+\mathrm{Na}]^{+}, 493[\mathrm{M}+\mathrm{K}]^{+} ;(-) \mathrm{ESI} m / z: 453[\mathrm{M}-\mathrm{H}]^{-}, 489[\mathrm{M}+\mathrm{Cl}]^{-}$. 


\section{Conclusions}

The oxidative coupling reaction of isorhapontigenin and resveratrol with $\mathrm{K}_{3} \mathrm{Fe}(\mathrm{CN})_{6} / \mathrm{NaOAc}$ in aqueous acetone as oxidant, in combination with silica gel column chromatography and preparative $\mathrm{Rp}-\mathrm{HPLC}$ resulted in the isolation of nine stilbene dimers. The structures of the nine dimers were determined on the basis of spectral analysis and chemical properties. Products 4, 6, and 7 are new dimers with indane skeletons, product 5 with an indane skeleton was obtained for the first time by direct transformation from isorhapontigenin, and all products would be rather difficult to obtain by common organic reactions.

Results indicated that, under the reaction conditions, the oxidative coupling reaction of two stilbenes yields only two types of stilbene dimers, namely, the benzofuran dimers 3 and $\mathbf{1 1}$ with the highest yields, and the indane dimers 4, 5, and 6-10 in comparatively low yields. Compared with other non-enzymatic oxidants (such as $\mathrm{FeCl}_{3}, \mathrm{Ag}_{2} \mathrm{O}, \mathrm{AgOAc}$, and so on), this reaction seems to generate only two types of radical intermediates, namely, $\mathrm{M}_{5}$ and $\mathrm{M}_{8}$, and only two coupling mechanisms occur to form benzofuran and indane stilbene dimers. Thus, the reaction could be used as a convenient method of synthesizing indane stilbene dimers because of its mild conditions, long reaction time and simple products. To the best of our knowledge, up to now, this is the most detailed report on the potassium hexacyanoferrate (III)-sodium acetate catalyzed biomimetic synthesis of stilbene dimers.

Supplementary Materials: Supplementary materials can be accessed at: http:/ / www.mdpi.com/1420-3049/20/ 12/19872/s1.

Acknowledgments: This work was financially supported by National Mega-project for Innovative Drugs (Grant No. 2012ZX09301002-001-003). We are grateful to the department of Instrumental Analysis, Institute of Materia Medica, Chinese Academy of Medical Sciences and Peking Union Medical College for measuring the IR, UV, NMR, and MS spectra.

Author Contributions: C.-S.Y., W.-S.Z. and J.-S.X. conceived and designed the experiments; J.-S.X., X.-F.W., J.W., J.-Q.Z., J.-F.Z. and Y.-L.K. performed the experiments; J.-S.X., J.-Q.Z. and C.-S.Y. analyzed the data; W.-S.Z., Y.-W.H. and J.W. contributed materials; C.-S.Y. and X.-F.W. wrote the paper.

Conflicts of Interest: The authors declare no conflict of interest.

\section{References}

1. Yao, C.S.; Wang, X.F. Naturally Active Oligostilbenes. J. Asian Nat. Prod. Res. 2016, in press.

2. Lin, M.; Yao, C.S. Natural oligostilbenes. Stud. Nat. Prod. Chem. 2006, 33, 601-644.

3. Li, W.L.; Li, H.F.; Luo, Y.L.; Yang, Y.H.; Wang, N. Biosynthesis of resveratrol dimers by regioselective oxidative coupling reaction. Synlett 2010, 8, 1247-1250. [CrossRef]

4. Snyder, S.A.; Zografos, A.L.; Lin, Y.Q. Total synthesis of resveratrol-based natural products: A chemoselective solution. Angew. Chem. Int. Ed. 2007, 46, 8186-8191. [CrossRef] [PubMed]

5. Snyder, S.A.; Breazzano, S.P.; Ross, A.G.; Lin, Y.Q.; Zografos, A.L. Total synthesis of diverse carbogenic complexity within the resveratrol class from a common building block. J. Am. Chem. Soc. 2009, 131, 1753-1765. [CrossRef] [PubMed]

6. Zhu, J.; Zhong, C.; Lu, H.F.; Li, G.Y.; Sun, X. Toward the synthesis of caraphenol C: Substituted effect on the nazarov cyclyzation of 2-arylchalcones. Synlett 2008, 3, 458-462.

7. Zhong, C.; Zhu, J.; Chang, J.; Sun, X. Concise total synthesis of $( \pm)$-isopaucifloral F, $( \pm)$-qaudranglarin A and ( \pm )-pallidol. Tetrahedron Lett. 2011, 52, 2815-2817. [CrossRef]

8. Li, W.L.; Li, H.; Li, Y.; Hou, Z.J. Total synthesis of ( \pm -quadrangularin A. Angew. Chem. Int. Ed. 2006, 45, 7609-7611. [CrossRef] [PubMed]

9. Snyder, S.A.; Gollner, A.; Chiriac, M.I. Regioselective reaction for programmable resveratrol oligomer synthesis. Nature 2011, 474, 461-466. [CrossRef] [PubMed]

10. Velu, S.S.; Buniyamin, I.; Ching, L.K.; Feroz, F.; Noorbatcha, I.; Gee, L.C.; Awang, K.; Wahab, I.A.; Weber, J.F.F. Regio- and stereoselective biomimetic synthesis of oligostilbenoid dimers from resveratrol analogues: Influence of the solvent, oxidant, and substitution. Chem. -Eur. J. 2008, 14, 11376-11384. [CrossRef] [PubMed] 
11. Takaya, Y.; Terashima, K.; Ito, J.; He, Y.H.; Tateoka, M.; Yamaguchi, N.; Niwa, M. Biomimic transformation of resveratrol. Tetrahedron 2005, 61, 10285-10290. [CrossRef]

12. Sako, M.; Hosokawa, H.; Ito, T.; Iinuma, M. Regioselective oxidative coupling of 4-hydroxystilbenes: synthesis of resveratrol and $\varepsilon$-viniferin (E)-dehydrodimers. J. Org. Chem. 2004, 69, 2598-2600. [CrossRef] [PubMed]

13. Wang, X.F.; Zhang, Y.; Lin, M.B.; Hou, Q.; Yao, C.S.; Shi, J.G. Biomimetic synthesis of active isorhapontigenin dimers. J. Asian Nat. Prod. Res. 2014, 16, 511-521. [CrossRef] [PubMed]

14. Zhang, Y.; Wang, X.F.; Hou, Q.; Lin, M.B.; Yao, C.S.; Shi, J.G. Preparation of active resveratrol dimeric derivatives by oxidative coupling reaction using AgOAc as oxidant. Chin. J. Org. Chem. 2014, 34, 886-892. [CrossRef]

15. Yao, C.S.; Lin, M.; Yang, Q.Y. Preparation of active gnetol dimers by oxidative coupling reaction and acid-catalyzed dimerization. Chin. J. Org. Chem. 2013, 33, 312-318. [CrossRef]

16. Yao, C.S.; Zhou, L.X.; Lin, M. Preparation on oligostilbenes of isorhapontigenin by oxidative coupling reaction. Chem. Pharm. Bull. 2004, 52, 238-243. [CrossRef] [PubMed]

17. Huang, K.S.; Wang, Y.H.; Li, R.L.; Lin, M. Stilbene dimers from the lianas of Gnetum hainanense. Phytochemistry 2000, 54, 875-881. [CrossRef]

18. Kim, H.J.; Saleem, M.; Seo, S.H.; Jin, C.; Lee, Y.S. Two new antioxidant stilbene dimers, parthenostilbenins A and B from Parthenocissus tricuspidata. Planta Med. 2005, 71, 973-976. [CrossRef] [PubMed]

19. Kawazoe, K.; Shimogai, N.; Takaishi, Y.; Rao, S.; Imakura, Y. Four stilbenes from Salacia lehmbachii. Phytochemistry 1997, 44, 1569-1573. [CrossRef]

20. Zhou, L.X.; Lin, M. A new stilbene dimer-shegansu B from Belamcanda chinensis. J. Asian Nat. Prod. Res. 2000, 2, 169-175. [CrossRef] [PubMed]

21. Ohyama, M.; Tanaka, T.; Iinuma, M. Five resveratrol oligomers from roots of Sophora Leachiana. Phytochemistry 1995, 38, 733-740. [CrossRef]

22. Khan, M.; Nabi, S.G.; Prakashi, S.; Zaman, A. Pallidol, a resveratrol dimer from Cissus pallida. Phytochemistry 1986, 25, 1945-1948. [CrossRef]

23. Roger, P.; Camille, P.; Junlien, B.J.; Raffaele, T.; Kartia, G.; Olivier, V. $\delta$-viniferin, a resveratrol dehydrodimer: One of the major stilbenes synthesized by stressed grapevine leaves. J. Agric. Food Chem. 2003, 51, 5488-5492.

24. Pilar, R.B.; Lorena, M.C.; Jose, M.L.; Francisco, G.C. Kinetic mechanism and product characterization of the enzymatic peroxidation of pterostilbene as model of the detoxification process of stilbene-type phytoalexins. Phytochemistry 2011, 72, 100-108.

25. Ponzoni, C.; Beneventi, E.; Cramarossa, M.R.; Raimondi, S.; Trevisi, G.; Pagnoni, U.M.; Riva, S.; Forti, L. Laccase-catalyzed dimerization of hydroxystilbenes. Adv. Synth. Catal. 2007, 349, 1497-1506. [CrossRef]

26. Wan, X.; Wang, X.B.; Yang, M.H.; Wang, J.S.; Kong, L.Y. Dimerization of piceatannol by momordica charantia peroxidase and $\alpha$-glucosidase inhibitory activity of the biotransformation products. Bioorg. Med. Chem. 2011, 19, 5085-5092. [CrossRef] [PubMed]

Sample Availability: Samples of the compounds are not available from the authors.

(C) 2015 by the authors; licensee MDPI, Basel, Switzerland. This article is an open access article distributed under the terms and conditions of the Creative Commons by Attribution (CC-BY) license (http:/ / creativecommons.org/licenses/by/4.0/). 